Ethiopian Journal of Environmental Studies \& Management 7(1): 31 - 42, 2014

ISSN:1998-0507

doi: http://dx.doi.org/10.4314/ejesm.v7i1.4

Submitted: October 2, 2013

Accepted: Juanuary 15, 2014

\title{
COMMUNITY PERCEPTIONS ON THE IMPACT OF DECENTRALISED FOREST MANAGEMENT ON ACCESS TO LIVELIHOOD ASSETS IN THE NORTH EASTERN AND CENTRAL TANZANIA
}

\author{
${ }^{*}$ MBWAMBO, L., ${ }^{1}$ MALIMBWI, R. E., ${ }^{2}$ AND KAJEMBE, G. C. ${ }^{2}$ \\ ${ }^{1}$ Tanzania Forestry Research Institute, P. O. Box 1854, Morogoro, Tanzania \\ ${ }^{2}$ Department of Forest Mensuration and Management, Sokoine University of Agriculture P. O. Box 3013, \\ Chuo Kikuu, Morogoro, Tanzania
}

\begin{abstract}
Community perceptions on the impact of decentralised forest management on access to livelihoods assets were assessed in north eastern and central Tanzania. Seven villages were selected from the montane and semi-arid conditions. In the montane, three villages; Goka, Sagara and Mavumo adjacent to Shagayu, Sagara and Shume-Magamba forests under Joint Forest Management (JFM), Community Based Forest Management (CBFM) and Centralised Management (CM) respectively were studied. In contrast, four villages namely Kwabaya, Kwamatuku, Pohama and Kweditilibe adjacent to Handeni Hill (JFM), Kwakirunga (CBFM), Mgori (CBFM) and Kiva Hill (CM) forests respectively were studied in semi-arid. Data were collected using semistructured questionnaires and the Statistical Package for Social Sciences (SPSS) 16.0 software was employed for data analysis. Decentralised management has to some extent facilitated and mediated access to forest related livelihood assets in the study villages. Presence of other projects and lack of baseline data however, made this study difficult to associate current access to livelihood assets with decentralised forest management. However, whether legally, or illegally people are using the forests to improve their livelihoods. Unapproved management plans and bylaws are a major governance problem facing implementation of decentralised forest management in Tanzania. Nevertheless, the two decentralised approaches (JFM and CBFM) have the potential to meet the general goals of improving forest resource condition, governance and livelihoods. Therefore further research to critically review strategies for improving forest governance and livelihoods is recommended.
\end{abstract}

Key words: community, perceptions, decentralised forest management, access, livelihood assets, north eastern and central Tanzania

\section{Introduction}

Forests and woodlands in Tanzania cover $51 \%$ (48 million ha) of the total country land area. Forests are essential resources for the disadvantaged sections of the society living in rural areas (Kaushal and Kala, 2004). In Tanzania mainland, forests and woodlands support livelihoods of over $80 \%$ of over 40 million people (URT, 2013). Access, assets and activities are important components of the sustainable livelihood framework (Ellis, 2000). For the purpose of this study, only assets endowment part of the sustainable livelihood framework is applied. Livelihood comprises assets (natural, physical, human, financial and social capitals), the activities and the access to these (mediated by institutions and social relations) that together determine the living of an individual or household (Ellis, 2000). Forests contribute to livelihoods in the form of daily household needs, income from formal employment and informal trading. Poor forest dependent people need access not only to forest resources but to several other assets to be able to obtain benefits from the forests (Larson et al., 2007). However, Tanzania is among countries where substantial forest loss has been recorded and estimated at $1.1 \%$ annually (FAO, 2010). In efforts to curb deforestation Tanzania introduced decentralised forest management through Participatory Forest Management (PFM) program with goal to improve forest condition, governance and livelihoods (URT, 1998; Blomley et al. 2008). 
PFM follows two approaches: Joint Forest Management (JFM) and Community Based Forest Management (CBFM). JFM is a collaborative management approach taking place on National Forest Reserves and Local Authority Forest Reserves or private forests which divides management responsibilities and benefits between the owner and adjacent communities. JFM is formalised by signing a Joint Management Agreement (JMA) between village representatives and government or private owner. CBFM takes place in registered Village Land Forest Reserves owned by the Village Councils (Blomley et al., 2008; URT, 2007). This legal transfer of ownership, use rights and management responsibilities to the village governments enable villagers to: harvest forest products, collect and retain forest revenues, arrest and fine offenders.

The two forms of decentralised forest management advocated in Tanzania benefit the communities differently. Under JFM the villagers are only allowed to use certain products including non-timber forest products. Depending on the type and status of the forest, CBFM is more beneficial as the Village Governments through the Village Forest Committees (VFCs) can sanction timber harvesting (URT, 2007). However, for the forests under CBFM in catchment forests where there is a logging ban, the benefits are limited just like in the case of JFM (Persha and Blomley, 2009).

Access to forest resources can increase household total income (Kamanga et al., 2009). Furthermore, Bebbington (1999) argued that, access to resources is the most critical asset that rural people need in order to build sustainable livelihoods. According to Ostrom (1999), vibrant and viable set of CBFM institutions is an important condition for communities to manage forests sustainably and support their livelihoods. Decentralisation theory and narrative believe that, devolution of forest management brings about sustainable improved rural livelihoods (Tacconi, 2007). It is claimed further that, decentralisation leads to distribution of benefits from forest resources more equitably (Agrawal et al., 2008) and can improve household economy. This is perhaps based on the understanding that decentralisation of forest management brings decision-making closer to the people and therefore yields programmes and services that better address local needs (Pacheco, 2004).

The aim of this study was to assess community perceptions on the impact of decentralised forest management on access to livelihood assets in the north-eastern and central Tanzania. One major challenge of measuring impacts is the question of "impact compared to what" (Dev et al., 2003). In the absence of baseline data, however, local user perceptions of resource trajectories and indicators are useful in assessing project impacts (Webb, et al., 2004). In this case, community perceptions were solicited in order to gather information on livelihoods for before and after decentralisation of forest management.

\section{Methodology \\ Study Sites}

This study was undertaken in Lushoto District at Goka, Mavumo and Sagara villages adjacent to Shagayu forest $\left(38^{\circ} 18^{\prime} \mathrm{E}, 4^{\circ} 30^{\prime} \mathrm{S}\right)$ under JFM, Shume-Magamba $\left(38^{\circ} 15^{\prime} \mathrm{E}, 4^{\circ} 40^{\prime}\right.$ S) under CM and Sagara $\left(38^{\circ} 30^{\prime}\right.$ E, $4^{\circ} 50^{\prime}$ S) under CBFM respectively in the montane forests. In contrast, four villages namely Kwabaya, Kweditilibe, Kwamatuku and Pohama adjacent to Handeni Hill (38 $30^{\prime}$ E, $5^{\circ} 27^{\prime}$ S) (JFM), Kiva Hill $\left(38^{\circ} 06^{\prime}\right.$ E, 5 $5^{\circ} 28^{\prime}$ S) (CM), Kwakirunga $\left(38^{\circ} 23^{\prime} \mathrm{E}, 5^{\circ} 14^{\prime} \mathrm{S}\right)(\mathrm{CBFM})$ in Handeni District and Mgori $\left(35^{\circ} 05^{\prime}\right.$ E, $4^{\circ} 45^{\prime}$ S) (CBFM) in Singida Rural District were studied in semi-arid forests (Figure 1).

Management and tenure regime changes for Shagayu, Sagara, Handeni, Kwakirunga and Mgori forest reserves took place in 2002, 1999, 1999, 2005 and 1996, respectively. Management regimes and forestland tenure for Shume-Magamba and Kiva reserves have remained unchanged. The villages were systematically selected based on their proximity to the forests, accessibility and their involvement in PFM activities. The studied montane forest reserves receive around $1000 \mathrm{~mm}$ annual rainfall at altitude between $1475-1800 \mathrm{~m}$ above sea level, while the semi-arid forests receive around $800 \mathrm{~mm}$ annual rainfall and are located between $700-1600 \mathrm{~m}$ above sea level. Number of adjacent villages, number of inhabitants and number of inhabitants per ha of forest among the reserves vary considerably (Table 1). 


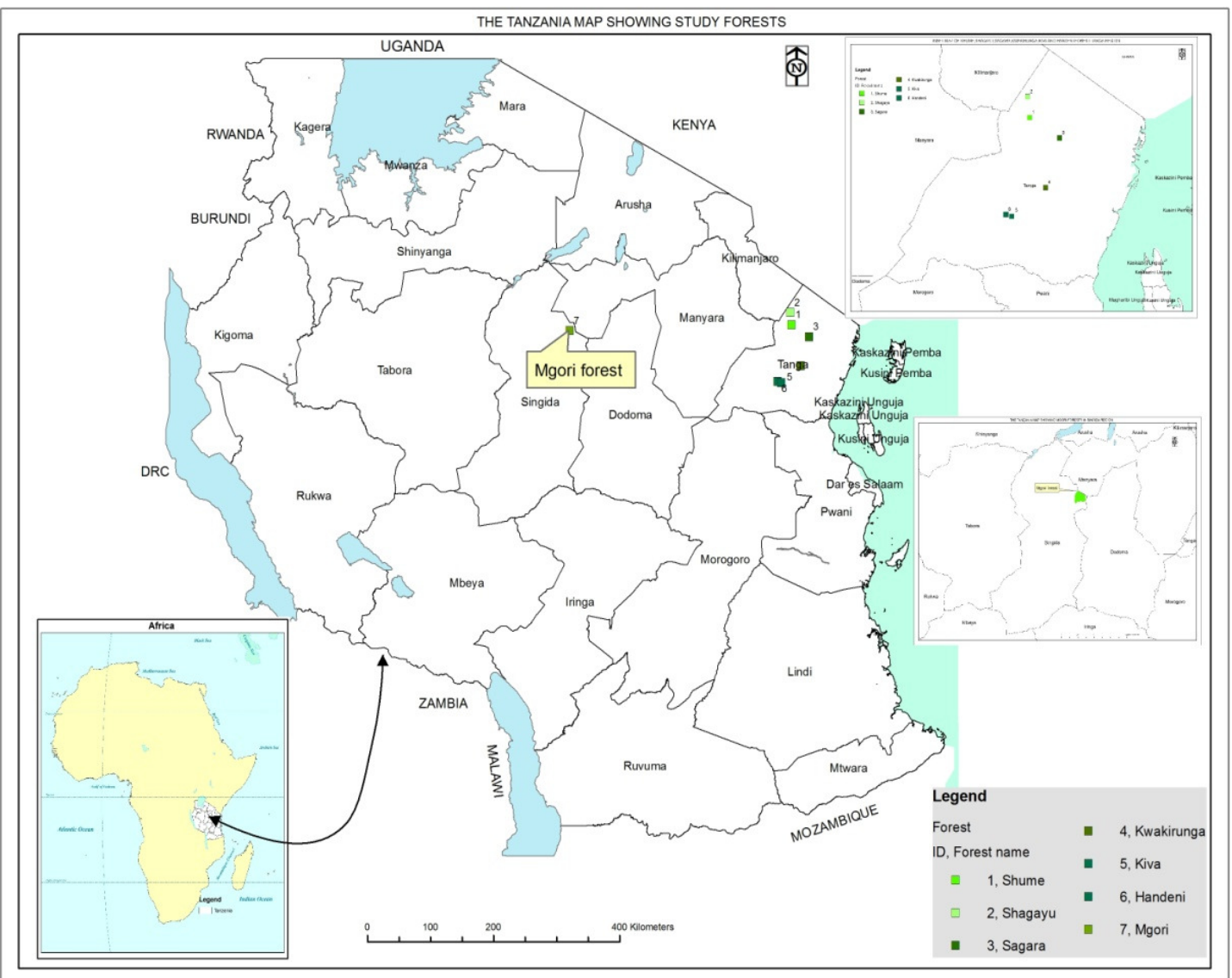

Figure 1: Location of study villages and forests

Table 1: Forest area, number of villages, population and population density in the forests surrounding selected study villages

\begin{tabular}{llllllll}
\hline Attributes & \multicolumn{7}{c}{ Forest name } \\
\cline { 2 - 8 } & Shagayu & Shume & Sagara & Handeni & Kiva & K/runga & Mgori \\
\hline Forest area (ha) & 7830 & 9284 & 256 & 544 & 655 & 227 & 39361 \\
Adjacent villages & 13 & 17 & 1 & 3 & 3 & 2 & 5 \\
Population & 27400 & 59000 & 1850 & 8800 & 7970 & 4067 & 10436 \\
People/ha of forest & 3.5 & 7.4 & 7.2 & 16.2 & 12.2 & 17.9 & 0.3 \\
\hline
\end{tabular}

\section{Data Collection}

Data were collected from 420 respondents on household characteristics and perceptions on access to the five livelihood capitals using a questionnaire survey. Mainly respondents' perceptions on the impact of decentralised forest management on access to capital assets were used due to lack of baseline data (Webb, 2004). Out of 420 interviewed respondents, $69.9 \%$ were males and $30.1 \%$ were females. The majority of respondents had age above 30 years and over $70 \%$ were married with family sizes of $6-10$ people. Over $70 \%$ of respondents had attained primary education while $30 \%$ had adult, secondary or no education at all. Major socioeconomic occupation of respondents is peasant agriculture followed by a combination of peasant agriculture and livestock keeping, government employment, petty business and other sources (Table 2). 
Community Perceptions on the Impact of Decentralised Forest Management................ MBWAMBO et al.

Table 2 Demographic and socio-economic description of respondents in study villages

\begin{tabular}{|c|c|c|c|c|c|c|c|}
\hline \multirow{3}{*}{ Variable } & \multicolumn{7}{|c|}{ Village response (\%) } \\
\hline & \multicolumn{3}{|c|}{ Montane villages } & \multicolumn{4}{|c|}{ Semi-arid villages } \\
\hline & $\begin{array}{l}\text { Goka } \\
(n=60)\end{array}$ & $\begin{array}{l}\text { Sagara } \\
(\mathrm{n}=60)\end{array}$ & $\begin{array}{l}\text { Mavumo } \\
(\mathrm{n}=58)\end{array}$ & $\begin{array}{l}\text { Kwabaya } \\
(\mathrm{n}=60)\end{array}$ & $\begin{array}{l}\mathrm{K} / \mathrm{matuku} \\
(\mathrm{n}=61)\end{array}$ & $\begin{array}{l}\text { Pohama } \\
(\mathrm{n}=60)\end{array}$ & $\begin{array}{l}\text { K/tilibe } \\
(\mathrm{n}=61)\end{array}$ \\
\hline \multicolumn{8}{|l|}{ Sex } \\
\hline Male & 53.3 & 75.0 & 56.9 & 63.3 & 78.7 & 76.7 & 85.2 \\
\hline Female & 46.7 & 25.0 & 43.1 & 36.7 & 21.3 & 23.3 & 14.8 \\
\hline \multicolumn{8}{|l|}{ Age } \\
\hline $18-30$ & 6.7 & 8.3 & 27.6 & 0 & 1.6 & 0 & 9.8 \\
\hline $30-50$ & 43.3 & 50.0 & 34.5 & 36.7 & 44.3 & 38.3 & 42.6 \\
\hline$>50$ & 50.0 & 41.7 & 37.9 & 63.3 & 54.1 & 61.7 & 47.6 \\
\hline \multicolumn{8}{|l|}{ Marital status } \\
\hline Married & 91.7 & 86.7 & 77.6 & 81.7 & 83.6 & 78.3 & 85.2 \\
\hline Single & 1.7 & 0 & 5.2 & 3.3 & 4.9 & 5.0 & 4.9 \\
\hline Widowed & 6.6 & 13.3 & 17.2 & 15.0 & 11.5 & 16.7 & 9.8 \\
\hline \multicolumn{8}{|l|}{ Family size } \\
\hline $0-5$ & 28.3 & 46.7 & 41.4 & 31.7 & 37.7 & 21.7 & 37.7 \\
\hline $6-10$ & 58.3 & 46.6 & 37.9 & 50.0 & 54.1 & 58.3 & 50.8 \\
\hline $11-15$ & 10.0 & 6.7 & 15.5 & 18.3 & 8.2 & 20.0 & 11.5 \\
\hline$>15$ & 3.4 & 0 & 5.2 & 0 & 0 & 0 & 0 \\
\hline \multicolumn{8}{|l|}{ Education } \\
\hline Primary & 95.0 & 61.7 & 77.6 & 61.7 & 72.1 & 75.0 & 70.5 \\
\hline Adult & 3.4 & 21.7 & 15.5 & 15.0 & 6.6 & 11.7 & 6.6 \\
\hline Secondary & 1.7 & 16.7 & 6.9 & 11.7 & 16.4 & 8.3 & 19.7 \\
\hline University & 0 & 0 & 0 & 0 & 0 & 0 & 0 \\
\hline No education & 0 & 0 & 0 & 11.7 & 4.9 & 5.0 & 3.3 \\
\hline \multicolumn{8}{|l|}{ Occupation } \\
\hline Peasant & 75.0 & 76.7 & 72.4 & 75.0 & 78.7 & 55.0 & 75.4 \\
\hline Livestock keeper & 3.3 & 0 & 3.4 & 0 & 0 & 6.7 & 0 \\
\hline Peasant/Livestock & 15.0 & 3.3 & 8.6 & 11.7 & 8.2 & 33.3 & 13.1 \\
\hline Govt employee & 1.7 & 10.0 & 5.2 & 5.0 & 8.2 & 3.3 & 9.8 \\
\hline Business & 1.7 & 3.3 & 5.2 & 6.7 & 3.3 & 1.7 & 1.6 \\
\hline Others & 3.3 & 6.7 & 5.2 & 1.7 & 1.6 & 0 & 0 \\
\hline
\end{tabular}

\section{Data Analysis}

The Statistical Package for Social Sciences (SPSS) 16.0 was used to analyse community perceptions data. Inferential statistical analysis was employed to compare means of responses on respondent's perceptions on the impact of decentralised forest management on access to livelihood capital assets. To do this, Analysis of Variance (ANOVA) was used to compare household mean scores for questions with responses on a five-point Likert Scale under the studied forest management regimes. The assumption was that household responses were continuous and each respondent took different stand points. F-test was therefore performed to test for significant differences.

\section{Results and Discussion \\ Access to Natural Capital}

Access to forest resources in this study was measured on a five-point Likert scale ( $1=$ very difficult, $2=$ difficult, $3=$ moderate, $4=$ =easy, $5=$ =ery easy) and the results are shown in Tables 3 and 4. Natural capital in the context of this study refers to forests only. According to Larson et al. (2007), for the local community to benefit from forest resources, access is of paramount importance. In this case decentralisation of forest management is hypothesised to lead to the transfer of forest use and access rights to participating communities. Overall perceptions on access to forests before decentralisation of forest management in the montane villages were rated difficult and the responses were significantly different $(\mathrm{p}<0.05)$. 
Table 3 Perceptions on access to forest resources under JFM, CBFM and CM before and after decentralisation of management in montane study villages, Lushoto District

\begin{tabular}{llllllllll}
\hline & & \multicolumn{3}{l}{ Before decentralisation } & \multicolumn{5}{c}{ After decentralisation } \\
\cline { 3 - 10 } Village & Regime & Mean & $\mathbf{N}$ & F-Test & Sign. & Mean & N & F-Test & Sign. \\
\hline Goka & JFM & 2.2 & 60 & & & 2.97 & 60 & & \\
Sagara & CBFM & 2.8 & 60 & & & 3.20 & 60 & & \\
Mavumo & CM & 2.9 & 58 & & & 3.12 & 58 & & \\
All & & 2.6 & 178 & 9.56 & $0.000^{*}$ & 3.09 & 178 & 0.61 & 0.54 \\
\hline
\end{tabular}

*Significant at $5 \%$ level

Table 4 Perceptions on access to forest resources under JFM, CBFM and CM before and after decentralisation of management in semi-arid study villages

\begin{tabular}{|c|c|c|c|c|c|c|c|c|c|c|}
\hline \multirow[b]{2}{*}{ Village } & \multicolumn{6}{|c|}{ Before decentralisation } & \multicolumn{4}{|c|}{ After decentralisation } \\
\hline & District & Regime & $\mathrm{N}$ & Mean & F-Test & Sign. & Mean & $\mathrm{N}$ & $\begin{array}{l}\text { F- } \\
\text { Test }\end{array}$ & Sign. \\
\hline Kwabaya & Handeni & JFM & 60 & 3.36 & & & 2.78 & 60 & & \\
\hline Kwamatuku & Handeni & CBFM & 61 & 3.33 & & & 2.80 & 61 & & \\
\hline Kweditilibe & Handeni & $\mathrm{CM}$ & 61 & 3.36 & & & 3.58 & 60 & & \\
\hline Pohama & Singida & CBFM & 60 & 2.55 & & & 3.08 & 61 & & \\
\hline All & & & 242 & 3.22 & 13.31 & $0.000^{*}$ & 3.06 & 242 & 8.32 & $0.000 *$ \\
\hline
\end{tabular}

*Significant at $5 \%$ level

Surprisingly, while other villages in the montane perceived access to be moderate after decentralisation, Goka village rated access to Shagayu forest to remain difficult plausibly due to imposed control by the VFC. However, regardless of management regimes, all studied forests in the montane were protected catchment forests with uses limited to non-timber forest products. Overall access perceptions of communities adjacent to semi-arid forests before decentralisation were rated moderate with exception of respondents from Pohama village adjacent to Mgori forest who perceived it to be difficult and the mean responses were significantly different $(\mathrm{p}<0.05)$. This was not surprising because Mgori was one of CBFM pilot project areas before the 1998 Forest Policy. Villagers in JFM and CBFM in Handeni semiarid forests claimed access to be difficult after decentralisation. Under CBFM access is sanctioned by the VFC, thus making it relatively easy for villagers to negotiate for permits as compared to forests under JFM. Shahbaz (2009) found that it was difficult for both villages under JFM and without JFM to access forests in Northwest Pakistan. Apart from management regime, access to forest resources may be difficult under corrupt systems (Brockington, 2007).
The owner of the forests under JFM and CM in the study forests is the State, making adjacent villagers unable to exclude distant villagers from appropriating forest products. Larson et al., (2007) argued that, forest access and security of that access are affected by tenure rights. Theoretically access to forest resources under decentralised management is vested to the Village Councils (Vyamana, 2009; URT, 2007). This study found that, VFCs, though lacking legal operational by-laws in all study forests, they control access of other village members to the forest. Forest Act require villagers adjacent to forests under $\mathrm{CM}$ to obtain access permits from the Forest Officers, however, this was not the case because these forests are under open access due to weak control under this regime. Thus people easily enter these forests without restrictions. In this case, the impact is positive on the community side for their livelihoods and negative on the forest condition due to degradation.

\section{Access to human capital}

Participation in seminars and meetings related to PFM were used as indicators for measuring impact of decentralised forest management on access to human capital (Tables 5 and 6). The majority of respondents in the montane study villages did not participate in 
seminars related to decentralised forest management and the responses were not significantly different. On the other hand, a large proportion of respondents in Goka village implementing JFM claimed to have attended meetings related to JFM. Plausible reason for this claim was that, this village had a series of meetings to develop and discuss management plans and bylaws in early 2000 during the introduction of JFM.

Table 5 Participation in seminars and meetings in montane study villages

\begin{tabular}{|c|c|c|c|c|c|c|}
\hline Variable & $\begin{array}{l}\text { Goka } \\
(\mathrm{n}=60)\end{array}$ & $\begin{array}{l}\text { Sagara } \\
(\mathrm{n}=60)\end{array}$ & $\begin{array}{l}\text { Mavumo } \\
(\mathrm{n}=58)\end{array}$ & $\begin{array}{l}\text { All } \\
(n=178)\end{array}$ & $\chi^{2}$ Test & Sign \\
\hline \multicolumn{7}{|c|}{ Participate in seminars } \\
\hline Yes & 40.0 & 33.3 & 43.1 & 38.8 & & \\
\hline No & 60.0 & 66.7 & 56.9 & 61.2 & & \\
\hline Total & 100 & 100 & 100 & 100 & 1.24 & 0.537 \\
\hline \multicolumn{7}{|c|}{ Participate in meetings } \\
\hline Yes & 70.0 & 48.3 & 53.4 & 57.3 & & \\
\hline No & 30.0 & 51.7 & 46.6 & 42.7 & & \\
\hline Total & 100 & 100 & 100 & 100 & 6.27 & $0.043 *$ \\
\hline
\end{tabular}

*Significant at $5 \%$ level

Table 6 Participation in seminars and meetings in semi-arid study villages

\begin{tabular}{llllllll}
\hline Variable & $\begin{array}{l}\text { Kwabaya } \\
(\mathrm{n}=60)\end{array}$ & $\begin{array}{l}\text { Kwamatuku } \\
(\mathrm{n}=61)\end{array}$ & $\begin{array}{l}\text { Pohama } \\
(\mathrm{n}=60)\end{array}$ & $\begin{array}{l}\text { Kweditilibe } \\
(\mathrm{n}=61)\end{array}$ & $\begin{array}{l}\text { All } \\
(\mathrm{n}=242)\end{array}$ & $\begin{array}{l}\chi^{2} \\
\text { Test }\end{array}$ & Sign \\
\hline Participate in & & & & & & & \\
seminars & & & & & & & \\
Yes & 30.0 & 41.0 & 70.0 & 66.7 & 43.4 & & \\
No & 70.0 & 59.0 & 30.0 & 33.3 & 56.6 & & \\
Total & 100 & 100 & 100 & 100 & 100 & 24.6 & $0.000^{*}$ \\
\hline Participate in & & & & & & & \\
meetings & & & & & & & \\
Yes & 75.0 & 62.3 & 85.0 .0 & 57.4 & 69.8 & & \\
No & 25.0 & 37.7 & 15.0 & 42.6 & 30.2 & & \\
Total & 100 & 100 & 100 & 100 & 100 & 13.6 & $0.004^{*}$ \\
\hline
\end{tabular}

*Significant at 5\% level

Households participating in different seminars and meetings are likely to capture different opportunities that may improve their livelihoods. With the exception of Pohama $(\mathrm{CBFM})$ and Kweditilibe (CM) villages in Singida and Handeni districts, respectively, which had $70 \%$ and $66.7 \%$ of respondents claiming to have attended different seminars, very low proportion of respondents had attended such seminars in other study villages. The high proportion of respondents who claimed to have attended different seminars in Pohama is not surprising because Mgori is among CBFM pioneer forests in Tanzania. Likewise high proportion of Kwabaya (75\%) and Pohama (85\%) respondents who claimed to have attended meetings can be associated with a series of meetings held in the process to put Handeni Hill and Mgori forests under JFM and CBFM respectively. Mgori forest showed improvement in terms of forest stocking and cover changes (Mbwambo et al., 2012a; Mbwambo et al., $2012 b)$ resulting perhaps from increased conservation awareness. Lugandu (2010) reported that JFM had improved human capital around New Dabaga Ulongambi Forest Reserve. Vyamana (2009) found that, at community level, available skills and to a limited extent health were impacted by PFM in the Eastern Arc Mountains.

It was learnt in this study that, at the inception of decentralised forest management, communities participated in seminars where they were trained on tree nursery establishment, tree 
planting, beekeeping, wood saving stoves and Participatory Forest Resource Assessment. However, these trainings were provided only during initial stages of PFM and have not continued due to limited funding. There were also claims that the trainings were biased towards VFC members. These findings are in agreement with Shahbaz (2009) who found that more livelihood schemes under JFM in Northwest Pakistan were accomplished in parts of the villages where village leaders lived. Vyamana (2009) reported on the issues of elite capture on access to livelihood capitals in forests under PFM in the Tanzania Eastern Arc Mountains.

\section{Access to Financial Capital}

This study assessed the potential of decentralised forest management in facilitating access to household financial assets. Initially, decentralised forest management was introduced with various Income Generating Activities (IGAs) including tree nurseries, wood saving stoves, brick making, and beekeeping. Unfortunately none of these exist in study villages due to discontinuity of PFM activities following shortage of funds. These IGAs are yet to be scaled up to cover the entire participating community in both montane and semi-arid study forest. This is similar to Ribot (2004) and Sunderlin et al. (2005) argument that, forest dependent groups are frequently being excluded from participating in higher IGAs in developing countries. Similarly, Vyamana (2009) reported that, IGAs in forests under JFM in the Eastern Arc Mountain forests were captured by village elites. This study found that the VFCs were allowed to confiscate illegal timber and charge fines, part of which (very subjective) was retained by the village governments and the rest used to pay allowances for forest patrol teams. These arrangements were not in place before decentralisation of forest management. However, due to poor record keeping and poor institutional memory no data were available at the offices in the study villages on the amount of revenues obtained from different forest management activities. However, CBFM allows for more consumptive forest uses including commercial harvesting of firewood, timber and charcoal making (URT, 2007) while the only permitted forest uses under JFM were basically non- consumptive such as research and ecotourism (Vyamana, 2009). This was the case with Sagara forest under CBFM because the forest is part of the catchment forests of West Usambara with restrictions on timber extraction. Ecotourism is one of potential opportunities as source of income in Sagara and Mgori forests under CBFM.

\section{Access to Physical Capital Village Infrastructure}

It was learnt in this study that, villages participating in decentralised forest management benefited more by getting timber to improve their school classrooms (desks, tables, chairs), office furniture and repair of bridges than nonparticipating villages. Similar arrangements are claimed to have made significant contributions elsewhere (Ribot, 2002). Decentralised forest management therefore, plays a role in improving infrastructure at the local level (Oyono, 2007). In Goka village practising JFM for example, they obtained timber from Shagayu forest to repair a bridge connecting Kisirui sub-village with other sub-villages, and this facilitated transportation of crops to the markets. Part of the timber was used to build a ward secondary school where now most of the children enrol for secondary education. In Kwabaya village practising JFM adjacent to Handeni Hill forest, the village government claimed to have used funds obtained from fines to rehabilitate their office. They also used confiscated timber to make office furniture. This is in line with Vyamana (2009) who found decentralised forest management providing small source of community-level income used to improve community physical capital in the Eastern Arc Mountains. Oyono (2007) working in Cameroon observed that rural infrastructure projects under community based forest management were fragmented and did not improve living conditions of forest adjacent communities.

\section{Houses}

On average $78.6 \%$ and $81.3 \%$ of houses were built mainly using a combination of poles, soil mud, sand and cement or poles only in montane and semi-arid study villages, respectively (Tables 7 and 8) regardless of their involvement in decentralised management. Higher reliance on poles for house construction has implications on the forest use and impacts on forest condition. 
Table 7 Type and house quality in montane studied villages

\begin{tabular}{|c|c|c|c|c|c|c|}
\hline & $\begin{array}{l}\text { Goka } \\
n=60\end{array}$ & $\begin{array}{l}\text { Sagara } \\
\mathrm{n}=60\end{array}$ & $\begin{array}{l}\text { Mavumo } \\
\mathrm{n}=58\end{array}$ & $\begin{array}{l}\text { Total } \\
\mathrm{N}=178\end{array}$ & $\chi^{2}$-Test & Sign \\
\hline Poles, mud & 61.7 & 58.3 & 55.2 & 58.4 & & \\
\hline Poles, sand, cement & 16.7 & 3.3 & 1.7 & 7.3 & & \\
\hline Poles only & 11.7 & 15.0 & 12.1 & 12.9 & & \\
\hline Mud bricks, sand, cement & 8.3 & 20.0 & 22.4 & 16.9 & & \\
\hline Burnt bricks, only & 1.7 & 3.3 & 8.6 & 4.5 & & \\
\hline Total & 100 & 100 & 100 & 100 & 19.7 & $0.032 *$ \\
\hline
\end{tabular}

*Significant at $5 \%$ level

Table 8 Type and house quality in semi-arid studied villages

\begin{tabular}{llllllll}
\hline House type & $\begin{array}{l}\text { Kwabaya } \\
\mathrm{n}=60\end{array}$ & $\begin{array}{l}\mathrm{K} / \text { matuku } \\
\mathrm{n}=61\end{array}$ & $\begin{array}{l}\text { Pohama } \\
\mathrm{n}=60\end{array}$ & $\begin{array}{l}\text { K/tilibe } \\
\mathrm{n}=61\end{array}$ & $\begin{array}{l}\text { Total } \\
\mathrm{N}=242\end{array}$ & $\chi^{2}$-Test & Sign \\
\hline $\begin{array}{l}\text { Poles, mud } \\
\begin{array}{l}\text { Poles, sand, } \\
\text { cement }\end{array}\end{array}$ & 65.0 & 73.8 & 65.0 & 72.1 & 69.0 & & \\
$\begin{array}{l}\text { Poles only } \\
\text { Mud bricks, sand, }\end{array}$ & 5.0 & 8.2 & 11.7 & 6.6 & 7.9 & & \\
$\begin{array}{l}\text { cement } \\
\text { Burnt bricks, only }\end{array}$ & 11.7 & 3.3 & 1.7 & 4.9 & 5.4 & & \\
Total & 15.0 & 13.1 & 1.6 & 14.8 & 11.2 & & \\
\hline
\end{tabular}

*Significant at $5 \%$ level

Housing quality differed significantly within all study villages. In the montane sites, Goka village practising JFM used more poles for housing than Sagara and Mavumo villages practising CBFM and $\mathrm{CM}$ respectively. A plausible explanation for this difference is that, the forest under CBFM is under strict protection rules restricting harvesting in catchment forests. Mavumo village with the forest under $\mathrm{CM}$ is influenced by the presence of sawmills processing logs from Shume-Magamba plantation, which offer employment to majority of the population and this might be improving their household economy although income assessment was beyond the scope of this study. There was no strong evidence to detect differences in housing quality in semi-arid villages, but a high proportion of houses built using wood are an indication of high dependence on forests for building materials regardless of PFM or no PFM. These findings are in agreement with Shahbaz (2009) who found villagers practising JFM using wood intensively to build new and repair old houses in Northwest Pakistan.
This study found that, $62.4 \%$ and $46.7 \%$ of households used corrugated iron sheets for roofing in montane and semi-arid villages, respectively. Over $50 \%$ of houses in semi-arid sites had thatched grass roofs indicating high reliance on forests as a source for thatch grasses.

\section{Energy}

Overall major source of energy in the montane study villages is a combination of firewood and kerosene (55\%), firewood only $(19.1 \%)$, kerosene only (16.9\%) and solar power (9\%) and the difference was strongly significant $\left(\chi^{2}=0.011, \mathrm{p}<0.05\right)$. All respondents $(100 \%)$ in Goka village under JFM used a combination of firewood and kerosene for energy. While no respondent used solar in Goka (JFM), 16.7\% and $10.3 \%$ of respondents in Sagara (CBFM) and Mavumo (CM) villages claimed to use solar power for lighting. Lack of diversified sources of energy around Shagayu forest might increase the demand for firewood and this call for concerted efforts to control harvesting. Charcoal was not a common source of energy in the montane villages 


\section{Ethiopian Journal of Environmental Studies and Management Vol. 7 No. 12014}

because traditionally charcoal is not produced in these areas, thus the use is limited.

Energy sources for villages in the semi-arid study villages followed a similar trend with addition of charcoal. The major source was a combination of firewood, kerosene and charcoal (79.8\%), kerosene only $(14.5 \%)$ and solar power $(5.9 \%)$ and differences between villages were significant $\left(\chi^{2}=53.4, p<0.05\right)$. Fifty percent of respondents from the village practising JFM used firewood alone for energy while $21.7 \%$ used a combination of firewood and kerosene. This was supported by data on tree harvests which showed higher removals in Handeni Hill than other forests (Mbwambo et al., 2012a, b). After forest improvement in Handeni Hill, the forest has turned to be a good source of firewood and poles. It is evident from these results that communities heavily depend on the natural capital as their major source of energy regardless of management regimes. An effort under PFM to introduce improved charcoal stoves in villages adjacent to Handeni Hill was not successful initially. Technological advancement like supply of affordable solar power could substantially substitute for natural capital and reduce pressure on forests (Ellis, 2000), but this is too far to be reached in the study forests.

\section{Access to social capital}

Indicators such as membership in village councils, social groups, presence of bylaws and compliance, and community empowerment were used to assess the impact of decentralised forest management on access to social capital (Tables 9 and 10).

Table 9 Access to social capital in montane study villages

\begin{tabular}{|c|c|c|c|c|c|c|}
\hline Indicator & $\begin{array}{l}\text { Goka } \\
(n=60)\end{array}$ & $\begin{array}{l}\text { Sagara } \\
(n=60)\end{array}$ & $\begin{array}{l}\text { Mavumo } \\
(\mathrm{n}=58)\end{array}$ & $\begin{array}{l}\text { All } \\
(n=178)\end{array}$ & $\chi^{2}$ Test & Sign \\
\hline \multicolumn{7}{|c|}{ Members in village council } \\
\hline $1-3$ & 66.7 & 20.0 & 20.7 & 36.0 & & \\
\hline None & 33.3 & 80.0 & 79.3 & 64.0 & & \\
\hline Total & 100 & 100 & 100 & 100 & 84.14 & $0.000 *$ \\
\hline \multicolumn{7}{|c|}{ Social groups } \\
\hline $1-3$ & 90.0 & 16.7 & 41.3 & 49.5 & & \\
\hline None & 10.0 & 83.3 & 58.7 & 50.5 & & \\
\hline Total & 100 & 100 & 100 & 100 & 87.9 & $0.000 *$ \\
\hline \multicolumn{7}{|c|}{ Existence of forest bylaws } \\
\hline Yes & 95.0 & 93.3 & 94.8 & 94.4 & & \\
\hline No & 5.0 & 6.7 & 5.2 & 5.6 & & \\
\hline Total & 100 & 100 & 100 & 100 & 2.63 & 0.62 \\
\hline \multicolumn{7}{|c|}{ Community empowered } \\
\hline Yes & 100 & 85.0 & 81.0 & 88.8 & & \\
\hline No & 0 & 15.0 & 19.0 & 11.2 & & \\
\hline Total & 100 & 100 & 100 & 100 & 11.9 & $0.003 *$ \\
\hline
\end{tabular}

*Significant at $5 \%$ level 
Table 10 Access to social capital in semi-arid studied villages

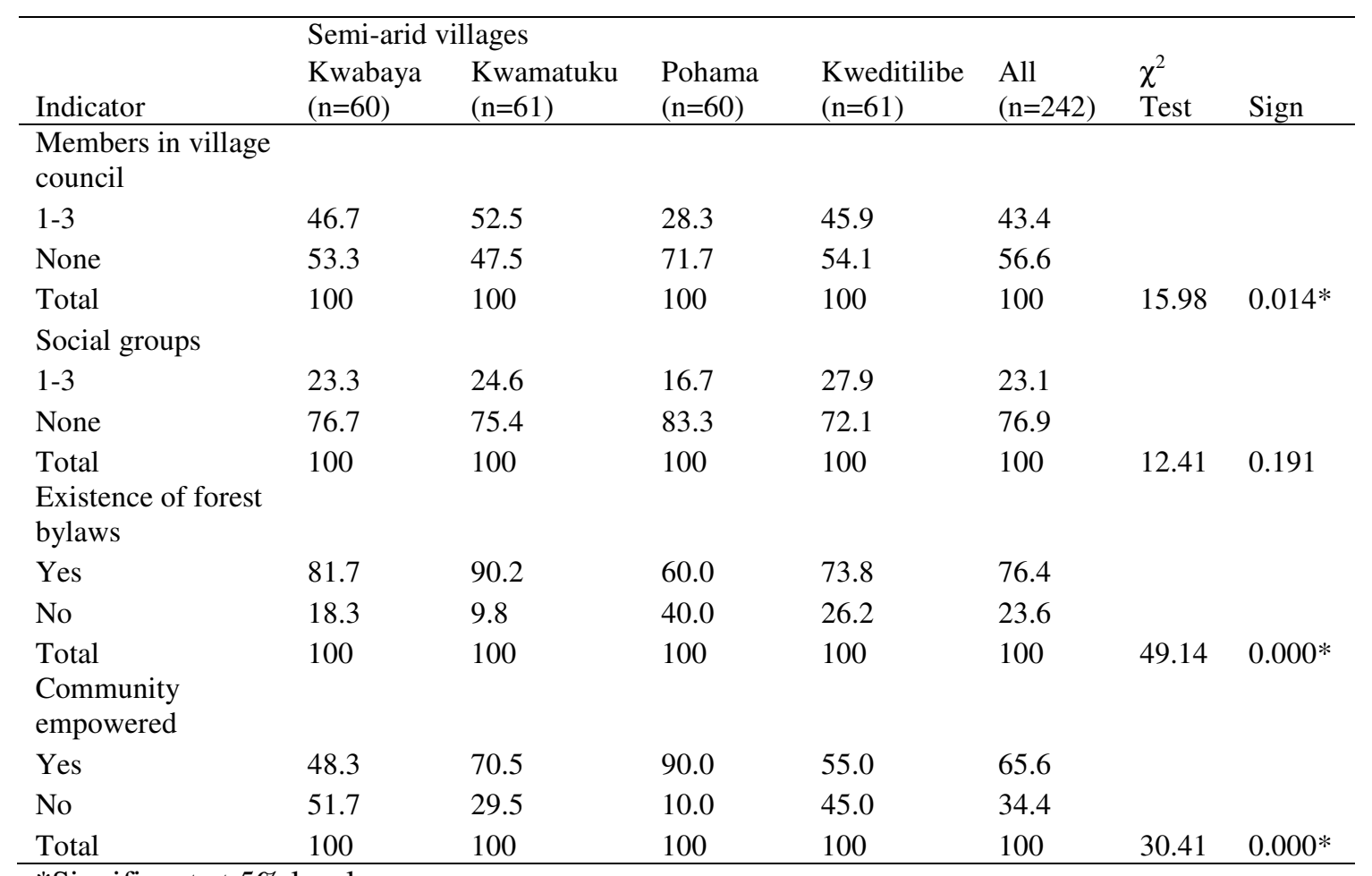

*Significant at $5 \%$ level

Grootaert and van Bastelaer (2001) in their analysis of several case studies suggested three social capital alternative indicators: i) membership in local associations and networks, ii) trust and compliance to norms and iii) collective action. Apart from Goka village (66.7\% of respondents) in the montane, a small proportion of respondents in other villages claimed to have at least 1-3 household members in the Village Council. For the semi-arid sites, $52.5 \%$ of respondents from Kwamatuku village under CBFM had at least 1-3 members of their households in the Village Council. Membership to the Village Council differed significantly in both sites and is biased to few households. In decentralisation, social capital is important in facilitating local people access to decision making bodies that influence their lives (Larson et al., 2007). Households connected with village government are likely to build strong social capital and enjoy first hand information on management and use of natural resources than their counterparts. Village governments are vested with powers to enact and enforce bylaws related to natural resource utilisation (URT, 2007; Vyamana, 2009) on which the rest of villagers must comply.

Existence of social groups is an important indicator of social capital in that regard. The respondents were asked to mention the number of existing social groups in their villages. For the montane sites, $90 \%$ of respondents from Goka village adjacent to Shagayu (JFM), claimed to have 1-3 social groups in their village. It was revealed during focus group discussions that, although not active currently, JFM initiatives introduced tree nursery groups in this village. Other social groups not related to JFM included Village Community Banks under Tanzania Social Action Fund, Vegetable Groups, Chicken Projects, Goat Projects introduced by the Participatory Agriculture Development and Empowerment Programme and other local women groups. In the semi-arid villages, regardless of involvement in participatory forest management, less than $30 \%$ of respondents 
indicated that there were 1-3 social groups in their villages, with majority claiming to have none. Regarding forest dependent groups, social capital is related to their ability to organise around their rights and make demands effectively (Larson et al., 2007). Social capital bonds societies together and in its absence no economic or human well-being (Grootaert and van Bastelaer, 2001).

\section{Conclusion}

It was found in this study that, apart from decentralised forest management, access to livelihood capitals at village level was also facilitated other projects. There were no community livelihood baseline data available in the study villages making it rather difficult to associate the current household livelihood capital assets with decentralised forest management. However, using community perceptions it was evident from this study that only natural capital could be directly related to the impact of decentralised forest management on livelihood. It was noted that, studied forests had draft bylaws and management plans developed at the onset of decentralised forest management but were yet to be signed to be operational, thus forest committees lacked the management instruments. Access to forests under JFM and CBFM in the montane and JFM in semi-arid sites was limited to collection of deadwood for fuel and other non timber forest products because they are essentially protected catchment forests. The forests under CBFM in the semi-arid sites have high potential to contribute to the livelihood of adjacent communities. However, Kwakirunga forest supposedly to be under CBFM has remained in defacto under open access, thus continues to be degraded. Under such a situation it has been difficult for the villagers to exclude other users from nearby villages. Nevertheless, the two decentralised approaches (JFM and CBFM) have the potential to meet the general PFM goals of improving forest resource condition, governance and livelihoods. Therefore further research to critically review strategies for improving forest governance and livelihoods is recommended.

\section{Acknowledgement}

This study was funded under the project "Assessing the impact of forestland tenure changes on forest resources and rural livelihoods in Tanzania" (NUFUTZ-2007/10226) under the Tanzania-Norway NUFU Programme (20072011). We are grateful to the anonymous reviewer whose comments improved our manuscript.

\section{References}

Agrawal, A., Chhatre, A. and Hardin, R. (2008). Changing management of the World's forests. Science 320: 1460 - 1462.

Bebbington, A. (1999). Capitals and capabilities: a framework for analysing peasant viability, rural livelihoods and poverty. World Development 27(12): 2021 - 2044.

Blomley, T., Kerstin, P., Isango, J., Zahabu, E., Ahrends, A. and Burgess, N. (2008). Seeing the wood for trees: an assessment of the impact of participatory forest management on forest condition in Tanzania. Oryx 42(3):380 - 391.

Brockington, D. (2007). Forests, community and local government performance: the Village Forest Reserves of Tanzania. Society and Natural Resources 20: 835 - 848.

Dev, O. P, Yadav, N. P, Springate-Baginski O, Soussan J. 2003. Impacts of communal

forestry and livelihoods in the middle hills of Nepal. Journal of Forest and Livelihood 3:64-77.

Ellis, F. (2000). Rural Livelihoods and Diversity in Developing Countries. Oxford University Press. 273pp.

FAO (2010). Global forest resources assessment 2010 main report. Food and Agriculture Organisation of the United Nations, Forestry Paper, No. 163, Rome. 378pp.

Grootaert, C. and van Bastelaer, T. (2001). Understanding and measuring social capital: a synthesis of findings and recommendations from the social capital initiative. The World Bank, Social Capital Working Papers Series. 31pp.

Kamanga, P., Vedeld, P. and Sjaastad, E. (2009). Forest incomes and rural livelihoods in Chiradzulu District, Malawi. Ecological Economics 68: 613 - 624. 
Kaushal, K. K. and Kala, J. C. (2004). Applying the sustainable livelihood approach to Joint Forest Management projects in India. International Forestry Review 6(1):13 - 18.

Larson, A. M., Pacheco, P., Toni, F. and Vallejo, M. (2007). The effects of forestry decentralisation on access to livelihood assets. Journal of Environment and Development 16(3): 251 - 268.

Lugandu, S. D. (2010). The impact of Joint Forest management on rural community livelihoods, forest cover and transaction costs: A case study of New Dabaga Ulongambi Forest Reserve in Kilolo District, Tanzania. Thesis for Award of $\mathrm{PhD}$ Degree at the Open University of Tanzania. 271pp.

Mbwambo, L., Eid, T., Malimbwi, R. E., Zahabu, E., Kajembe, G. C. and Luoga, E. 2012a. Impact of decentralized forest management on forest conditions in Tanzania. Forests, Trees and Livelihoods, Pp 1-17.

Mbwambo, L., Kashaigili, J. J., Eid, T., Malimbwi, R. E., Zahabu, E., Kajembe, G. C., Luoga, E.and Kayeye, H. 2012b. Impact of decentralised forest management on forest cover changes in the North Eastern Tanzania. Tanzania Journal of Forestry and Nature Conservation, Volume 82(1), Pp $50-67$.

Ostrom, E. (1999). Self-governance and forest resources. CIFOR Occassional Paper No. 20.

Oyono, P. R. (2007). Is decentralisation in natural resource management leading to livelihood improvement and sustainability? Evidence from Central Africa. In: Proceedings of the International Conference on Participatory Forest Management (PFM), Biodiversity and Livelihoods in Africa. (Edited by Kelbessa, E. and De Stoop, C.), $19-21$ March 2007, Addis Ababa, Ethiopia. pp. 19 -35 .

Pacheco, P. (2004). What lies behind decentralisation? Forest, Powers and Actors in lowland Bolivia. European Journal of Development Research 16(1): 90 - 109.

Persha, L. and Blomley, T. (2009). Management decentralisation and montane forest conditions in Tanzania. Conservation Biology 23(6): 1485 - 1496.

Ribot, J. C. (2002). African decentralization: local actors, powers and accountability. United Nations Research Institute on Social Development (UNRISD) Program on Democracy, Governance and Human Rights. Paper No. 8. Geneva: UNRISD. 89pp.

Ribot, J. C. (2004). Waiting for democracy. The politics of choice in natural resource decentralisation. World Resources Institute. WRI Report, 140pp.

Shahbaz, B. (2009). Dilemmas in participatory forest management in Northwest Pakistan: A livelihoods perspective. Department of Geography, University of Zurich, Switzerland. Vol 25, 182pp.

Sunderlin, W. D., Angelsen, A., Belcher, B., Burgers, P., Nasi, R., Santoso, L. and Wunder, S. (2005). Livelihoods, forests and conservation in developing countries: an overview. World Development 33(9): 1383 $-1402$.

Tacconi, L. (2007). Decentralisation, forests and livelihoods: theory and narrative. Global Environment Change 17: 338 - 348.

URT, (1998). The National Forest Policy. United Republic of Tanzania Government Printer, Dar es Salaam, Tanzania. 59pp.

URT (2007). Community Based Forest Management Guidelines: For the Establishment of Village Land Forest Reserves and Community Forest Reserves. Ministry of Natural Resources and Tourism, United Republic of Tanzania. $57 \mathrm{pp}$.

URT (2013). 2012 Population and housing census, National Bureau of Statistics, Ministry of Finance. Dar Es Salaam, United Republic of Tanzania. 264pp.

Vyamana, V. G. (2009). Participatory forest management in the Eastern Arc Mountains of Tanzania: who is benefiting? International Forestry Review, Vol II (2): 239-253.

Webb, E. L., Maliao, R. J. And Siar, S. V. (2004). Using local user perceptions to evaluate outcomes of protected area management in the Sagay Marine Reserve, Philippines. Environmental Conservation 21(2):138 148. 